\title{
Códigos de deontología periodística: análisis comparativo*
}

\section{Porfirio Barroso Asenjo**}

\section{Introducción}

Entendemos por código la interpretación de los principios generales de una profesión y de las actitudes a observar en las actividades profesionales. Es la ordenación sistemática de principios, normas y reglas establecidos por un grupo profesional, en nuestro caso los periodistas, para orientar su propia vida, con el fin de regular y dirigir la conducta de sus miembros y sus relaciones mutuas (Fairchild, 1963. Citado por Grazziosi, 1978: 11). Un código deontológico es de esta forma la constelación de criterios y principios o normas y reglas que de forma explícita y sistematizada un grupo profesional se compromete a respetar y seguir en sus comportamientos como tales profesionales. Los códigos de ética o principios deontológicos se consideran un requisito esencial en la configuración de una profesión. Manifiestan la toma de conciencia de una profesión y el comportamiento debido, para que se considere una práctica como práctica profesional. Son en todo caso la fuente primaria de toda ética o deontología profesional. En el caso concreto del periodista, el código ético supone una interpretación de los principios generales de la profesión periodística y de las actividades profesionales, es decir, supone una cristalización de los principios a seguir para obtener una conducta correcta y adecuada al buen hacer del periodista o profesional de la información y comunicación.

En cuanto a los códigos deontológicos de la profesión periodística, los podemos definir como un conjunto de "principios y normas de conducta profesional de los periodistas referentes a sus derechos, deberes y responsabilidades éticas". Tiina Laitila se ha ocupado de estos temas y nos brinda algunas definiciones (Laitila cit. en Nordenstreg,1995: 29). Un código ético periodístico hace referencia al establecimiento de unos principios éticos destinados a servir como guías en el ejercicio de la profesión periodística, adoptados y controlados por la propia profesión.

\footnotetext{
Ponencia presentada en el II Congreso "Ética de la comunicación y comunicación ética”, Conferencia Episcopal de Colombia, Bogotá, 7-9 de octubre de 2009.

** $\quad$ Profesor titular de la Universidad Complutense de Madrid, Departamento de Periodismo, experto en análisis sobre Ética y Deontología. Profesional en observaciones fenomenológicas de la comunicación. E-mail: pbarroso@ccinf.ucm.es
} 


\section{Definición de Deontología}

La palabra castellana deontología arranca, como tantas otras en nuestro idioma, de la lengua griega. En concreto de $\delta \varepsilon o v=$ participio neutro del verbo impersonal $\delta \varepsilon i$, que significa: "lo obligatorio, lo justo, lo adecuado, lo conveniente, el deber. El otro vocablo griego es hoyos que significa: tratado, investigación, estudio, ciencia. La deontología concretiza hoy la generalidad de la perspectiva ética refiriéndola a los deberes, reglas y normas de una profesión. Esto en cuanto a su definición etimológica o nominal. Fue el filósofo y jurisconsulto inglés Jeremy Bentham (1748-1842) quien acuñó por primera vez, que se sepa, el termino deontología cuando recurrió a los dos términos mencionados para forjar el vocablo Deontology, en su libro: Deontology, or the Science of Morality, publicado como obra póstuma por sus discípulos, dada la importancia del contenido científico de esta obra en el año 1834. Este fue -para mí- el creador del término "Deontología". Tanto éxito tuvo esta obra que en el mismo año se tradujo y fue publicada en lengua francesa. La influencia llegó también a España y fue traducida al español en dos volúmenes; el primero en el año 1935; y, el segundo, un año mas tarde. Deontología entendida como la ciencia que está constituida por todas las normas objetivas para una colectividad profesional, sea cualquiera el grado de positivación. En sentido estricto deontología es el conjunto de normas de menor grado de positivación y que no están respaldadas por una sanción estatal. Por último, el belga Leon Duwaerts la definía como la ciencia o, si este término parece pretencioso, el estudio que trata de los deberes que hay que cumplir, es decir, las reglas profesionales, que en nuestro caso concreto, deontología son las normas que deben cumplir los periodistas en el ejercicio diario de su profesión y que se encuentran -como veremos-, en los códigos deontológicos de la actividad informativa.

\section{Cronología de aparición de los códigos éticos del periodista}

El primer código del que tenemos memoria en el mundo es el Código de Hammurabi, que data del año 2200 a.C. Y viene a ser el primer esbozo de reglamentación legal y ética del ejercicio de la medicina. Le seguiría, en antigüedad, el Juramento de Hipócrates, del año 500 a.C. Se puede considerar como 
el primer código deontológico del periodista al "credo" de Benjamín Harris, publicado en Boston en 1690, que tiene grandes coincidencias y similitudes con los códigos modernos. Está considerado como el primer código mundial de la ética periodística, pues se considera que en aquellos años la profesión periodística no era reconocida como tal. Harris, enfatiza la recogida de noticias y su difusión con verdad, objetividad, exactitud y de forma completa, puesto que las medias verdades -dice él-, equivalen a mentiras. En caso de que por cualquier motivo estas normas no se cumplieran, Harris promete la corrección de errores cuando estos tengan lugar, y evitar a toda costa los falsos rumores: reemplazarlos o sustituirlos por informaciones reales y objetivas. Harris insistía en que todo periódico tenía la obligación de redactar o transmitir noticias. Reconoce que una de las funciones de la prensa es evitar la circulación de falsos rumores y sustituirlos por informaciones verídicas. Por último, Harris y sus seguidores prometieron exactitud y objetividad en sus informaciones. En esto coincide con los resultados obtenidos con la suma de todos los códigos de los periodistas de la Unión Europea como veremos en el cuadro resumen.

Tras un vacío de dos siglos, la sección austriaca de la Asociación de Periodistas Polacos reconoció en sus normas, establecidas en el año 1896, que las cortes de honor y ellos mismos tenían previsto establecer "una obligación de obedecer unas normas de moral periodística". Ese mismo año se estableció el Estatuto de la Unión de Periodistas Polacos de Galitzia obligando a los miembros de esta unión a cargar con el deber de respetar la ética periodística.

El siguiente hito en la historia de los códigos de ética de los periodistas, lo tenemos en el Código de Suecia, primer código escrito en el siglo XX, aunque no fue ampliamente aceptado. Uno de los primeros códigos de ética periodística fue adoptado en Francia en 1918, cuando el Sindicato Nacional de Periodistas adoptó la Carta de Conducta. Este documento fue revisado posteriormente en los años 1938 y 1966. Sin salirnos de la vieja Europa encontramos la publicación el día 30 de mayo de 1918 del Standards of Practice of the British Association of Trade and Technical Journals.

El código de ética de prensa de Noruega fue adoptado por la Asociación de la Prensa de Noruega, originariamente en el año 1936 y revisado posteriormente en los años 1956, 1966 y 1975. En los últimos años cuarenta, la unión Nacional Británica de Periodistas adoptó el Código de Conducta Profesional. Gran proli- 
feración de códigos deontológicos de periodismo en la segunda mitad del siglo XX. Amplio despliegue de códigos en los años cincuenta de ese siglo. Se publicó el Código de ética periodística belga, en 1951. En junio de 1957 el Consejo de Prensa Italiana daba luz verde a los Principios de ética profesional. La Asociación de editores de Revistas en la República Federal de Alemania elaboró el Código de ética en 1957. Un año más tarde, el Consejo de Nacional de Prensa de Alemania aprobó el Código de ética profesional del periodista alemán. De incontables podríamos calificar los códigos publicados en las tres últimas décadas del siglo XX y que nosotros mismos hemos publicado ya en otra obra (Barroso, 1991: 194-218).

Estos son los nombres más comunes dados a estas normas deontológicas: "Códigos éticos, Códigos de Prácticas, Códigos de Conducta, Códigos deontológicos, Códigos de honor, Principios o normas de conducta profesional" están hoy tan extendidos que puede decirse que no existe organización profesional de periodistas que no tenga su propio código deontológico. También los grandes periódicos de tirada nacional cuentan ya con su propio código como veremos más tarde el referirnos al caso de España.

\section{Estudio de los códigos de ética periodística de los 27 países de la Unión Europea}

A la hora de emitir un informe sobre un estudio actual de cómo está la situación de la teoría y práctica de la ética periodística de la Unión Europea, se nos ocurrió realizar un estudio de campo de la única fuente primaria de toda la Deontología Periodística, cuáles son los códigos éticos de los distintos países que conforman, al día de hoy, la Unión Europea. Se trataba de hacer un análisis de contenido de todos ellos y posteriormente un estudio comparativo. Estos son sus resultados: 

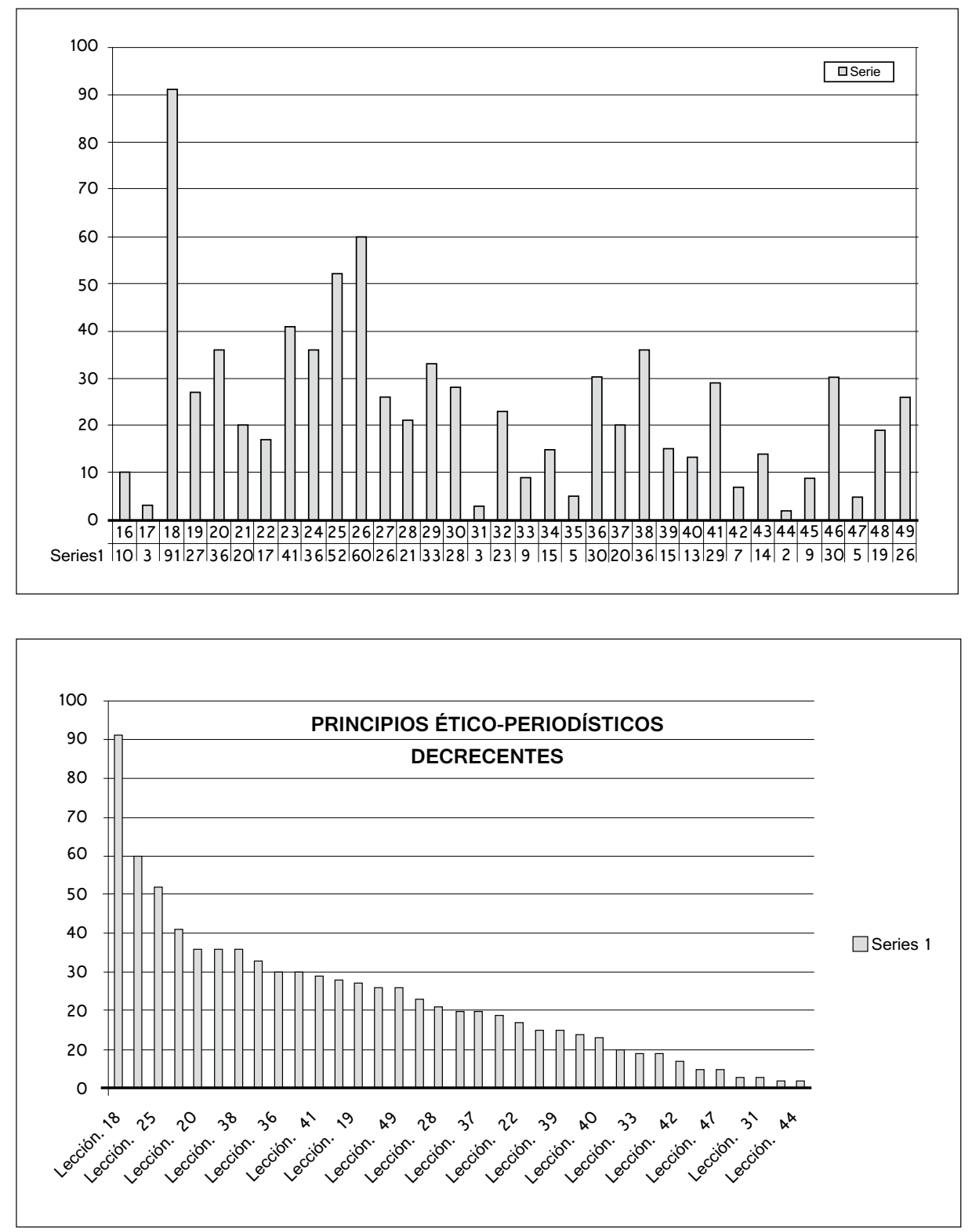
La lectura e interpretación de los datos obtenidos es como sigue: en primer lugar, no solo cuantitativamente con una frecuencia de 91 veces, dato que se refleja, el primer principio ético-periodístico, lección 18, que es el servicio que el periodista debe hacer a la verdad, la objetividad, la exactitud y la precisión, en virtud del derecho de ley natural que el público tiene a conocer lo más posible la verdad. También afirmamos que de forma cualitativa, pues éste es uno de los conceptos que suele aparecer siempre entre los primeros artículos de los códigos de estos 27 países de la Unión Europea. En segundo lugar está la lección 26 que corresponde a la primacía del servicio al bien común, bien público o bien social, con una frecuencia de 60. En tercer lugar y con una frecuencia de 52 se encuentra la lección o tema de la libertad de expresión y la libertad de prensa, por supuesto con la consabida responsabilidad del periodista. En cuarto lugar tenemos la lección 23 que es la corrección de errores y el derecho de rectificación y réplica por parte de la empresa informativa. Empatan en la frecuencia 36, tres temas o lecciones: la 20 que se refiere a la integridad profesional del periodista, que dice que éste no debe admitir soborno alguno, tanto como para publicar lo que no debe como para omitir lo que debe; en este mismo ranking se encuentra la lección 24, acerca de la obligación que tiene el periodista de respetar la intimidad y vida privada de las personas, así como los datos de carácter personal o íntimo; por último con la misma frecuencia o porcentaje esta la lección o tema de la deontología sobre crímenes y suicidios, dado el peso específico que a esta materia dan los códigos de los países nórdicos, con vistas a que se pueda recuperar a los menores delincuentes. La lección 29, con una frecuencia de 33 le sigue en importancia cuantitativa y trata sobre el tema de que el periodista, mientras ejerza su profesión en un medio de comunicación de entidad pública, no puede al mismo tiempo hacer ni publicidad ni propaganda, ni inmiscuirse en negocios que puedan implicar conflictos de interés o que prefiera a su interés personal al bien común de los demás. Otro empate a 30 de frecuencia se produce con las lecciones 36 , se refiere al respeto que el periodista debe tener con los derechos de autor, es decir, siempre debe mencionar la fuente de dónde obtiene la información y no caer en el plagio; le sigue la lección 46 que trata el tema de la identidad de los delincuentes, dice que ni los nombres, ni las fotografías deben aparecer en la prensa, éste responde al tema constitucional del derecho a la juventud y a la infancia. En solitario camina la lección 41 que 
trata de que el periodista está obligado a comprobar la veracidad de sus fuentes de información y mencionarlas si así se lo exigen. Con una frecuencia de 28 veces se encuentra la lección 30 que lleva por título: el periodista debe utilizar solamente justos y honestos medios en la consecución de sus informaciones y noticias. Una de las lecciones más importantes desde nuestro punto de vista y que además es un tema constitucional, es el derecho y del deber de guardar el secreto profesional y no revelar ni sus fuentes, ni los of the record ni las confidencias ni nada que el comunicante quiera que quede fuera de micrófono. La frecuencia es solo de 27. Vuelven a empatar a 26 puntos las lecciones 27 y 49 que tratan de la no discriminación por parte del periodista, por ningún motivo, y que el periodista está obligado a cumplir en conciencia, en el foro interno, como norma y no como ley el Código de ética profesional respectivamente. La lección 32 que se refiere al fotoperiodismo y a la ética que debe seguirse en cuanto a las fotografías de prensa, tiene una frecuencia de 23 veces. Con 21 de frecuencia se encuentra la lección 28 , a través de la cual el periodista debe aceptar siempre la responsabilidad de sus escritos, además de identificarse como profesional en servicio en el ejercicio de su actividad informativa. Otra de las lecciones es la 21, se refiere al tema del honor, dice que el periodista no debe calumniar ni difamar ni injuriar, ni acusar sin fundamento, así como debe respetar el honor de las personas, este es el primer límite constitucional a la libertad de expresión en nuestra Constitución de 1978. Sin embargo, llama la atención, en este estudio de contenido sobre los códigos de los 27 países de la Unión Europea, que estadísticamente solo aparece con una frecuencia de 20 veces. La lección 22 que trata el tema de la dignidad, la honestidad y la honradez de las personas y del compromiso que tiene el periodista a ser leal a su empresa y a sus compañeros, solo le conceden a este tema una frecuencia de 17 veces. Con una frecuencia de 15, encontramos dos lecciones: la 34 y la 39, que se refieren a la solidaridad y el espíritu de cuerpo que debe reinar entre los periodistas y la clausula de conciencia, respectivamente. Con 14 frecuencias vemos la lección 43 que señala la obligación del periodista de respetar las instituciones sociales, tales como: la Iglesia, el Estado, el Parlamento, la Constitución y las leyes. Con frecuencia de entre 13 y 5 vemos las siguientes lecciones o temas: no al sensacionalismo periodístico, ética del informador periodístico, el derecho que todo periodista tiene a recibir un salario digno y justo como todo profesional, 
incompatibilidad del periodista con otros cargos mientras este ejerciendo como periodista, no incitación a la violencia, crimen o robo. El resto de lecciones ya no son estadísticamente significativas por sus bajas frecuencias en los 27 códigos de la Unión Europea.

\section{Analizamos a continuación país por país de la Unión Europea por orden alfabético a excepción de España que como se nos pidió, la dejamos para el último lugar.}

Alemania. La libertad de prensa garantizada en la Constitución Política de la República Federal de Alemania comprende la independencia y la libertad para difundir información, así como para expresar opiniones y críticas. Del país germano, lo más destacable es la importancia que dan a los temas de la verdad, objetividad, exactitud, precisión y la libertad y la responsabilidad de la prensa. Así como al secreto profesional del periodista y no revelación de las confidencias y de sus fuentes de información y no someterse a ninguna clase de soborno o influencia externa. Tienen además en consideración la primacía del servicio al bien común o bien del público en general, rompiendo una lanza a favor de la igualdad de tratamiento a todo el mundo y la no discriminación por ningún motivo. Resaltan también la ética en la fotografía de prensa y no dejarse influir por el sensacionalismo periodístico. Este código es uno de los más largos de la Unión Europea.

Austria. Los principios de deontología periodística de Austria fueron adoptados en 1983 por el Consejo de Prensa, y actualizados en enero de 1999. Destaca de este código la importancia dedicada al principio de toda ética periodística. La obligación del periodista de servir a la verdad, de la forma más objetiva y exacta posible, en virtud del derecho natural que el público tiene a conocerla, es la frecuencia más repetida en este código. Hasta siete veces. Le sigue con seis veces el servicio al bien común y bien público, como opuesto a los conflictos de interés y a los intereses privados de los periodistas, que deben ser pospuestos a los intereses del público y de la empresa. Le siguen en importancia los conceptos del respeto a la intimidad y la vida privada de las personas y a los datos de carácter personal e íntimo, así como a la propia imagen. También con la misma frecuencia aparece la dedicación que hace este código al fotoperiodismo y, en 
particular, la prudencia y la ética que hay que observar en la fotografía de prensa. Por último, el código resalta en cuarto lugar la integridad que debe tener el periodista en todo momento de su ejercicio profesional y no dejarse sobornar, ni para publicar noticias ni para silenciarlas u ocultarlas.

Bélgica. Hay que destacar en este código sobre los demás principios deontológicos, la libertad de la prensa como la principal salvaguarda de la libertad de expresión, sin la cual la protección de las otras libertades ciudadanas, fundamentales, no estarían aseguradas. La prensa, afirma el código, debe tener el derecho de reunir y publicar, sin obstáculos, informaciones y comentarios para asegurar la formación de la opinión pública crítica y madura. A esto dedica el código cinco párrafos, seguido de tres que pertenecen a la obligación del periodista de decir la verdad, ser objetivo, exacto y preciso lo más posible en sus informaciones con tres menciones y con tan solo dos párrafos dedicados a que el periodista debe ser observador de la justicia y promotor de los derechos humanos. Los demás artículos solo son mencionados en una sola ocasión.

Bulgaria. Aunque Bulgaria adoptó las reglas de la ética periodística en octubre de 1990, sin embargo como nosotros solo estudiamos los códigos en vigor, hemos acudido a su último código vigente, desde el 6 de marzo de 1994. Fue adoptado en esta ocasión por el Décimo Congreso de la Unión de Periodistas Búlgaros, con el nombre de Reglas de Ética Periodística. Este es uno de los códigos más cortos de estos países de la Unión Europea y es uno de los mejores, ya que solo en una ocasión, cuando trata del servicio al bien común o bien público y bien de los demás, en esa única ocasión, el concepto se repite dos veces en su articulado; los demás principios solo aparecen en un artículo, lo que es muestra evidente de una buena redacción de un código, pues no se debe repetir nada más que una vez. ¿Para que más? A pesar de su brevedad encontramos todos los principios deontológicos clásicos de todo buen código de ética periodística. Como son: la verdad, el secreto profesional, la dignidad, la honestidad, la honradez, la corrección de errores y el derecho de réplica, la libertad y la responsabilidad de la prensa, primacía del servicio al bien común, la no discriminación por ningún motivo, que el periodista no debe hacer publicidad ni propaganda y que debe utilizar solamente los justos y honestos medios para adquirir la información. 
Chipre. El código de Chipre resalta en su articulado la primacía al servicio al bien común o bien público, y la corrección de errores y el derecho de replica, que se repiten en más de un lugar del código. Los demás principios aparecen solo en un lugar y son los más importantes de la Deontología Periodística, como: la verdad, el secreto profesional, la corrección de errores y el derecho de réplica, el respeto a la intimidad, la defensa de la libertad de expresión, el servicio al bien del público, utilizar solamente justos y honestos medios para adquirir información, tener en cuenta el fotoperiodismo y la ética en la fotografía de prensa; respeto al derecho de autor; se debe distinguir lo que es noticia de lo que es su comentario y cómo se debe informar sobre crímenes y suicidios.

Dinamarca. Como es sabido los códigos deontológicos obligan solo en conciencia, en el foro interno, interiormente. Su obligación, por tanto, es moral más que legal. Obligan solo como norma de comportamiento, nunca como ley positiva. Sin embargo, como toda regla tiene su excepción, el caso de Dinamarca y Eslovaquia son las dos únicas excepciones de todos los códigos de los países de la Unión Europea, que obliga no solo como norma, sino también como ley positiva, pues fueron aprobados por sus respectivos parlamentos. En el caso de Dinamarca el Código Nacional de Conducta para todos los periodistas daneses tiene rango de ley al ser aprobado por el Parlamento de Dinamarca, con la aceptación de la Unión Nacional de Periodistas Daneses, en 1992. La salvaguarda de la libertad de palabra en Dinamarca está estrechamente conectada con el libre acceso de la prensa a las fuentes de información y con las noticias para su correcta publicación. El libre comentario es parte del ejercicio de la libertad de palabra. Atendiendo a esas metas, la prensa reconoce que el ciudadano, como individuo, merece respeto a su integridad personal y a la probidad y a su vida privada. De ahí la necesidad de protección contra violaciones injustificadas. Quebrantar la práctica saludable de la prensa implica retener la publicación de noticias veraces de esencial importancia para el público, y ser dócil frente a ello puede suscitar dudas tanto de la libertad como de la independencia de los medios de comunicación. También se considera un quebrantamiento a la correcta práctica periodística si el ejercicio del periodismo en conflicto con estas reglas proviene de un periodista. Un periodista no debe aceptar tareas contrarias a sus convicciones personales. Es de destacar que uno de los principios que se repite con más frecuencia en este código se refiere a que el 
periodista danés debe informar sobre los crímenes y los suicidios, y que todo el mundo es inocente mientras no se demuestre que es culpable, por parte de un tribunal competente. Hasta cuatro veces recoge este concepto el código danés solo igualable en frecuencia con los principios deontológicos de la verdad y de la primacía al servicio al bien común.

Eslovaquia. Veíamos como una segunda excepción a la regla general el que los códigos son principios y normas, y no leyes positivas; esto se repite en este caso con el Código de Ética del Sindicato de Periodistas Eslovacos, al ser aprobado por el Parlamento de ese país y por el sindicatos de Periodista el día 19 de octubre de 1990. Por lo tanto, en este segundo caso también, el código de los periodistas eslovacos les obliga, no solo a su cumplimiento como norma, sino como ley positiva. Los derechos, las obligaciones y deberes de los periodistas dimanan de los derechos del público, en este caso del conocimiento de la verdad, y son los periodistas los únicos profesionales encargados de transmitir la verdad de forma más objetiva, exacta y precisa que su subjetividad les permita. Por eso, el principio de que el periodista debe servir a la verdad, aparece en este código en más de una ocasión, a la vez que no a la calumnia, a las acusaciones sin fundamento, a las difamaciones, como la libertad y la responsabilidad de la prensa, la primacía del servicio al bien público, comprobar las fuentes de información y su mención y la obligación del periodista de no hacer publicidad ni propaganda mientras trabaje como redactor en un medio de comunicación de titularidad pública, estos son los temas más socorridos en este código. Los demás principios solo aparecen en una sola ocasión.

Eslovenia. El Nuevo Código de Ética de los Periodistas eslovenos es uno de los más recientes en la Unión Europea, pues data tan solo del 10 de octubre de 2002, desde cuando fue adoptado por la Unión de Periodistas en Eslovenia. La obligación fundamental de los periodistas eslovenos es proporcionar al público una auténtica y verdadera información. El periodista informa como testigo o basándose en los hechos y pruebas que tienen un origen conocido. Omitir hechos cruciales y conocidos, ocultar y distorsionar información, o falsificar documentos, es contrario al espíritu del presente Código. La norma de veracidad, que es el principio de la verdad, debe ser respetada en textos, imágenes y sonidos. Cualquier violación hecha por cortar, editar o cualquier otro medio ilegítimo que altere el mensaje verdadero de la fuente es inaceptable. Es 
un derecho del periodista reunir y transmitir información y reportajes de casos donde el acceso a la información ha sido infundada e ilegalmente restringida. No en vano la norma de todo periodista esloveno es ser lo más fiel posible a la verdad, objetividad, exactitud y precisión, en virtud del derecho que el pueblo esloveno tiene a conocer dicha verdad. Este principio deontológico es el segundo en orden de frecuencias, precedido únicamente por la primacía del servicio por parte del periodista al bien público, bien común o bien de la comunidad en general, que hemos contabilizado al menos hasta cinco veces en el texto de este código. Se detiene este código en conceptos como: la integridad profesional del periodista esloveno o el hecho de que él no se deje sobornar, ni por omitir información ni por publicarla. Es también importante para estos periodistas la obligación moral y legal de corregir sus errores y rectificar, tan pronto como se den cuenta, de las faltas cometidas o bien porque el público se acoge a este derecho. Uno de los principios no muy frecuentes en estos códigos es la obligación moral de todo periodista esloveno de ser responsable de todo cuanto publique, así como de presentarse como tal periodista en el ejercicio de su actividad informativa. Una de sus responsabilidades concretas es la de no hacer ni publicidad ni propaganda mientras ejerza como periodista en un medio público de información y de comunicación. Por último, debe cumplir con la obligación de comprobar la veracidad de sus fuentes de información, y de mencionarlas si el público así se lo demanda.

Estonia. Recientemente se ha adoptado el Código de Ética para la Prensa en Estonia. Este código es usado solamente por el segundo organismo que lo ha adoptado, que es el Consejo de Prensa de Estonia. Pensamos que a pesar de ser bastante largo y moderno, sin embargo, no es eficiente. Su estructura es diferente a los demás: consta de grandes apartados como: principios generales, independencia, fuentes, línea editorial, el derecho de réplica y rectificación y publicidad. Repite muchísimo los mismos principios. Dedica seis frecuencias al servicio al bien público o bien social, hasta en cuatro ocasiones se ocupa de la verdad, objetividad, exactitud, la libertad de prensa y su responsabilidad, o que el periodista de Estonia, no debe hacer ni publicidad ni propaganda; repite tres veces la idea del secreto profesional del periodista de Estonia, o se refiere en varias ocasiones a la corrección de errores y el derecho de rectificación y réplica, a que ni los nombres ni las fotografías de los niños y jóvenes deben apa- 
recer en la prensa, insiste en que los periodistas debemos proteger a la juventud y a la infancia. Dedica en más de una ocasión al tema de los principios éticos como: no a la calumnia, acusaciones infundadas, difamaciones y faltas al honor a la honestidad y a la vida privada e íntima de las personas; se fija en que el periodista debe aceptar la responsabilidad por sus escritos, el derecho de autor y la mención de la fuente; repite más de una vez la deontología sobre crímenes y suicidios, la cláusula de conciencia y el deber del periodista de comprobar la veracidad de sus fuentes de información. Por todo ello creemos que los autores de este código no han tenido en cuenta las reglas básicas de cómo se debe formular un buen código de deontología periodística, que debería dedicar un solo artículo a cada uno de los principios ético-periodísticos. -Me reservo la responsabilidad de esta opinión-.

Finlandia. La Guía para la Buena Práctica Periodística en Finlandia fue aprobada por la Unión de Periodistas de Finlandia, en noviembre de 1991. Entró en vigor a partir del 1 de enero de 1992. En este código se puede ver la intervención y la ciencia de nuestro buen y viejo amigo, Kaarle Nordenstreng, Director del Departamento de Periodismo y Medios de Comunicación Social de la Universidad de Tampere en Finlandia, además de ser una de las mayores autoridades y especialista en ética periodística, cuenta con estudios sobre códigos en esta materia en la Unión Europea. Nosotros somos deudores de muchas de sus enseñanzas y publicaciones. Este código finlandés consta de 29 artículos diseminados en los siguientes apartados o capítulos que nos resumen maravillosamente su contenido principal. Son estos: Introducción, en la que se afirma entre otras cosas que la base de una buena práctica periodística reside en el derecho del ciudadano a una correcta y esencial información, mediante la cual pueda formar una imagen realista del mundo y de la sociedad que lo rodea. La ética profesional de un periodista implica el respeto de los valores humanos básicos, como los derechos humanos, la democracia, la paz y el entendimiento internacional. Un periodista debe reconocer su responsabilidad con el entorno y debe estar vigilante de sus efectos en las cuestiones que trata. La buena práctica periodística no se limita al propio periodista ni a la libertad de expresión del público. Debe tender a promover la discusión y la fluidez informativa e implicar la responsabilidad con los principios y políticas de comunicación. La buena práctica periodística también implica el conocimiento periodístico de las más 
importantes leyes, regulaciones, acuerdos internacionales y resoluciones relacionadas con su trabajo. Otros títulos de los restantes capítulos son estos: Status profesional, información correcta, la adquisición de la información, corrección de errores y derecho de réplica y, finalmente, protección de los individuos.

Francia. Código adoptado por el Sindicato Nacional de Periodistas Franceses en 1918, fue reformado en 1938, lo que hace que sea uno de los más antiguos de los países de la Unión Europea. Existen también los "Dieciocho Principios Éticos para los Periodistas de Radio y de Televisión. Además, como ellos mismos expresan, se trata de una lista que fue aceptada en enero de 1994 por 200 periodistas de la TF1, de la red de Televisión francesa que es la de mayor audiencia en el país galo. Se entiende que no se trata propiamente de un código en cuanto tal, ni siquiera de una carta de ética periodística, sino de unos "principios" que un periodista de radio y de televisión está obligado a respetar en su ejercicio profesional. No analizamos, ni estudiamos estos así llamados "principios", aunque sean más recientes, porque nuestro informe se centra únicamente en los códigos de la prensa escrita. Consta de 15 artículos que resumen toda la deontología periodística francesa de esta manera: Un periodista digno de ese nombre: Asume la responsabilidad de todos sus escritos, incluso los anónimos. Considera la calumnia, la difamación y las acusaciones sin pruebas, la alteración de los documentos, la deformación de los hechos y la mentira, como las más grandes faltas profesionales. Solo reconoce la jurisdicción de sus colegas, soberana en materia de honor profesional. Solo acepta las misiones compatibles con su dignidad profesional. Se tiene prohibido a sí mismo invocar un título o una cualidad imaginaria para obtener una información o sorprender la buena fe de la gente. No recibe dinero de un servicio público ni de una empresa privada donde su calidad de periodista, sus influencias, sus relaciones podrían ser susceptibles de ser explotadas. No firma con su nombre artículos que aludan a publicidad comercial o financiera. No comete ningún plagio. Cita a los colegas de los que reproduce un texto cualquiera. No solicita la plaza de un colega ni provoca su despido, ofreciéndose para trabajar en condiciones inferiores. En conjunto, a pesar de su antigüedad es un buen código, ya que solo repite los mismos principios en cinco ocasiones reforzando o insistiendo en los conceptos de: el respeto al honor, la dignidad, la honradez, la honestidad, la fama de las personas, la defensa del periodista de la libertad de prensa, teniendo en cuenta 
su propia responsabilidad, hacen corporativismo al insistir sobre la importancia de la solidaridad profesional y el espíritu de cuerpo entre los periodistas, y por último, defiende sus derechos de autor y que no se les debe plagiar sin mencionar la originalidad de las fuentes.

Grecia. El primer código de Grecia, del cual tenemos noticia, fue adoptado por la Asociación de Editores de Diarios de Atenas, el 2 de julio de 1978. El código actual lleva por nombre "Principios de Ética de los Medios de Comunicación Social", fue aprobado el 31 de octubre de 1988, por cinco sindicatos de periodistas griegos. La Unión de periodistas de prensa diaria de Atenas, la unión de periodistas de prensa diaria de Macedonia, la Unión de periodistas de prensa diaria de Peloponissos, Epirus y las Islas, la Unión de periodistas de prensa diaria de Thessaly, Sterea, Evia y de la Unión de periodistas de la prensa periódica. Todos ellos adoptaron este Código. En 1990, formó parte del contrato entre la unión de periodistas de Atenas y los dirigentes de la cadena pública ERT de Grecia. Estos principios éticos se pueden resumir así. Los miembros de la Asociación de Editores de Diarios de Atenas en sus relaciones profesionales, así como en el ejercicio de su profesión, respetarán los principios de ética profesional establecidos tanto en los muchos años de práctica periodística como en los estatutos de las organizaciones internacionales de periodistas y en el presente ordenamiento: La profesión periodística es una misión social, ya que para el código de los periodistas griegos, el ejercicio del periodismo profesional, más que un oficio, o una profesión, se trata de una verdadera vocación o misión. La presentación de la verdad es el principal estímulo de los periodistas griegos. Siempre y en todas partes, los periodistas griegos son garantes de la libertad de expresión, de la difusión libre y sin cortapisas tanto de juicios de valor como de hechos noticiosos, así como del derecho a disentir. Las convicciones religiosas, relaciones, hábitos y costumbres de las personas, nacionalidades y razas, así como la vida familiar y privada de las personas, son sagradas e intocables. La tarea cardinal de los periodistas es apoyar las libertades nacionales, los sistemas democráticos, así como las relaciones entre Estado y sociedad. El respeto a los valores populares y nacionales y el apoyo a los intereses nacionales deben inspirar a los periodistas en el ejercicio de su profesión. Mientras ejerzan la profesión, los periodistas deberán rechazar cualquier presión tendiente a suprimir contenidos periodísticos o a distorsionar la verdad. Los periodistas deben tener 
un acceso libre y sin trabas a las fuentes de información. La observancia del secreto profesional y la confidencialidad de las fuentes de información son consideradas como el principal deber y derecho de los periodistas y de los miembros de la Asociación de Editores de Diarios de Atenas. La misión del periodismo no debe ser utilizada para fines personales. Los periodistas no aceptan ninguna ventaja, remuneración o promesa de pago ofrecida como un contravalor por la limitación de independencia de sus opiniones durante el ejercicio de su trabajo profesional. Según nuestro criterio evaluativo, este Código es un buen ejemplo de que no se deben repetir los conceptos innecesariamente. Solo refuerza tres principios repitiéndolos en dos ocasiones. Recalca la importancia de que el periodista griego sirva a la verdad, respete la primacía del bien público antes que su bien o beneficio personal y finalmente, caso raro, los periodistas griegos acatan el que deben respetar las instituciones sociales como: la Iglesia Griega, el Estado, el Parlamento, la Constitución, las leyes, así como a otras instituciones sociales.

Hungría. El Código de Ética de los Periodistas Húngaros fue adoptado por la Asociación Nacional de Periodistas Húngaros (MUOSZ) en 1994. Su largo contenido le podemos resumir señalando solo los principales capítulos o titulares que son éstos. El objetivo de este instrumento normativo es preservar y promover actividades periodísticas éticas y honestas dentro del entramado de los derechos humanos, la vida pública y democrática y el Estado constitucional. Capítulos a destacar son: la libertad y responsabilidad de los periodistas húngaros. La violación a las regulaciones de conducta. La violación de la libertad de debate y crítica. Los abuso de la libertad periodística. Otros casos de ofensa ética. Decisiones del Comité de Ética y provisiones misceláneas. Cada uno de estos capítulos se subdivide en artículos que explicitan y concretizan más el título genérico del capítulo. A nuestro juicio no se trata de un buen código representativo del estándar de todo código de ética periodística, pues hay conceptos muy repetidos hasta la saciedad como es el caso de la obligación del periodista de decir la verdad, ser lo más objetivo en imparcial posible, este concepto tiene una frecuencia de seis veces repetidas en distintos artículos. También da una gran importancia a la obligatoriedad del periodista de defender la libertad de expresión, el derecho a la información y a la libertad de prensa que es repetida hasta en cuatro veces en distintos lugares del Código. Otros principios de me- 
nor importancia son reiterados en más de una ocasión, lo que hace que al menos este Código húngaro no se atenga a las normas lógicas de una buena estructuración de un código deontológico.

Irlanda. La Unión Nacional de Periodistas de Irlanda, aprobó el día 29 de junio de 1994, el llamado Código de Conducta de Irlanda. Que consta de un do decálogo de doce artículos que resumimos a continuación brevemente. El periodista irlandés tiene el deber de mantener los más altos estándares profesionales y éticos. Un periodista siempre deberá defender el principio de la libertad de prensa al recolectar y difundir información y al expresar comentarios y críticas. Deberá asegurarse de que la información que disemina es justa y exacta, evitar la expresión de comentarios y conjeturas como hechos establecidos, y rehuir la falsificación. Un periodista deberá rectificar rápidamente cualquier inexactitud dañina, y permitir el derecho de réplica a las personas criticadas. Un periodista deberá obtener información, fotografías e ilustraciones solamente por medios honestos. Los periodistas están autorizados para ejercer la objeción personal de conciencia en el uso de tales medios. Salvo por preeminentes consideraciones de interés público, un periodista deberá evitar intrusiones en la aflicción privada y el dolor humano. Un periodista deberá proteger las fuentes confidenciales de información. Un periodista no deberá aceptar sobornos, ni permitir la influencia de terceros en el ejercicio de sus deberes profesionales. Un periodista no deberá prestarse a la distorsión o a la supresión de la verdad por motivos publicitarios o por otras consideraciones. Un periodista solo deberá mencionar la edad de las personas, raza, color, credo, origen genealógico, enfermedad, estado civil, sexo u orientación sexual, si tal información es estrictamente relevante. Un periodista no deberá tomar ventajas personales de la información obtenida en el ejercicio de sus deberes. Un periodista no deberá -por medio de una declaración, opinión o imagen- anunciar cualquier producto comercial. Este es un buen código, según nuestro criterio, pues solo es reiterativo en tres temas que son muy importantes dentro de la ética periodística, la defensa que debe hacer el periodista a favor de la verdad, la objetividad y exactitud posibles en la información, el servicio al bien público y común, antes que a sus intereses personales y que el periodista no se debe dedicar a hacer publicidad ni propaganda mientras ejerza como tal periodista en un medio de información de titularidad pública. Estos temas son repetidos en este código. 
Italia. Código adoptado por la Federación Nacional de la Prensa Italiana y el Consejo Nacional del Orden de los Periodistas, el 8 de julio de 1993. El código de los periodistas italianos lleva por título: Carta de los deberes de los periodistas. En la introducción de este código que afirma que: el trabajo del periodista italiano, se inspira en los principios de la libertad de información y de opinión, sancionados por la Constitución italiana y está regulado por el Art. 2 de la Ley número 69, del 3 de febrero de 1963, que dice así:

Es derecho inalienable de los periodistas la libertad de información y de crítica, limitada por la observancia de las normas legales que protegen los derechos personales de los demás. Es obligación insoslayable el respeto a la verdad sustancial de los hechos y cumplir siempre los deberes impuestos por la lealtad y la buena fe. Deben ser rectificadas las noticias que resulten inexactas, y subsanados los eventuales errores. Periodistas y editores deben respetar el secreto profesional sobre la fuente de las noticias cuando lo requiera el carácter confidencial de éstas, y promover el espíritu de colaboración entre colegas, la cooperación entre periodistas y editores, y la confianza entre la prensa y los lectores.

La relación de confianza entre los órganos de información y los ciudadanos es la base de trabajo de todos los periodistas. Para promover y hacer más sólida esa relación, los periodistas italianos suscriben el siguiente pliego de obligaciones, que al ser muchas las resumimos mencionando solo los grandes titulares de los diversos capítulos. Inicia con un apartado dedicado a los principios generales de la ética periodística. Continúa con otro capítulo dedicado a las responsabilidades que atañen a los periodistas italianos. Habla de la obligación de la rectificación y réplica, de la presunción de inocencia, de las fuentes de información, de la relación entre informaciones y publicidad, las incompatibilidades del periodista en el ejercicio de su profesión, y se acuerda finalmente de los menores y los discapacitados. Sin embargo, pensamos que al ser tan largo y explicitar cada uno de estos apartados detalladamente es demasiado reiterativo y repetitivo en estos mismos temas, que bastaría con haber explicado cada uno de los títulos de los capítulos en lugar de repetir cada uno de esos conceptos esenciales muchas veces en diferentes artículos en los que se subdivide cada capítulo. Por tanto, si nos atenemos a las normas de la lógica y de una buena estructura este es un mal código. 
Letonia. Código adoptado por la Conferencia de la Unión de Periodistas Letones, el 28 de abril de 1992. Consta de seis capítulos cuyos titulares son: el papel de los medios de comunicación social en la sociedad; integridad y responsabilidad; responsabilidad editorial; relaciones con las fuentes; reglas de publicación y periodistas; $y$, sociedad. Cada uno de estos apartados se subdivide en artículos que explicitan, concretan y amplían en contenido en el titular. Consideramos que es un buen código, pues solo resalta repitiendo cuatro veces en distintos artículos el concepto de verdad, objetividad, exactitud, precisión y no manipulación de la información. Tres artículos los dedica a la defensa de la libertad de expresión, información y prensa. Repite más de una vez los principios éticos de: el derecho de corrección y réplica, comprobar la veracidad de las fuentes de información, la obligación que tienen los periodistas letones de respetar las instituciones sociales y, finalmente, la obligación de todo periodista de ser garantes de la justicia y la defensa de los derechos humanos.

Lituana. Código de Ética de los Periodistas Lituanos. Fue adoptado por la Unión de Periodistas lituanos, por la Asociación de periodistas lituanos, por la Asociación de Editores de Revistas, por la Asociación Lituana de Radio y de Televisión y por el Centro de Periodismo Lituano el día 25 de marzo de 1996. Consta este código de 63 artículos que se corresponden con los capítulos dedicados a la verdad, la honestidad, la decencia, a la independencia del periodismo y su responsabilidad, a la protección del honor personal, de la dignidad y de la intimidad y vida privada, a las relaciones que deben guardar los periodistas entre sí, y así como a la solidaridad profesional y al espíritu de cuerpo entre los mismos, Esto hace que al ser un código bastante extenso sea reiterativo en los mismos principios éticos, los que por orden de frecuencia decreciente serían éstos: la verdad y la objetividad son las que más veces repiten hasta llegar a sumar nueve veces, le siguen la obligatoriedad del periodista de comprobar la veracidad de sus fuentes de información, el que ni los nombres ni las fotografías de los jóvenes delincuentes aparezcan en la prensa, unido a esto el concepto de la protección de la juventud y de la infancia. Otros temas repetidos varias veces eran la integridad del periodista y no dejarse sobornar, la corrección de errores y el derecho de replica, el derecho de autor y la mención de fuentes, distinguir lo que es noticia de lo que es un comentario, como se debe informar sobre crímenes y suicidios, defensa de la libertad de expresión, el periodista no 
debe hacer ni publicidad ni propaganda, solidaridad profesional del periodista y espíritu de cuerpo o corporativismo profesional, el secreto profesional y otros temas de menor importancia son muy repetidos en este mal código en cuanto a su estructura y su lógica.

Luxemburgo. El Código Deontológico de la Prensa de Luxemburgo fue aprobado por la Asamblea Plenaria del Consejo de Prensa de Luxemburgo, el 4 de diciembre de 1995; contiene, en resumen, los siguientes principios deontológicos. El primer concepto es el derecho a la información y a la libertad de expresión tal como está garantizada por la Constitución y afirmada por la Declaración de los Derechos del Hombre, se deriva la responsabilidad del periodista y el editor. Tal responsabilidad implica: El respeto a la verdad, a la libertad de opinión de otros, así como a la dignidad humana y la vida privada. El compromiso de publicar información de fuentes fiables. De acatar el secreto profesional que implica el derecho a no revelar sus fuentes de información Separar la relación de hechos y los comentarios en forma apropiada. La prohibición del plagio, la ofensa, la injuria, la difamación, la calumnia y la discriminación racial, étnica, religiosa e ideológica. La obligación de abstenerse de una presentación exagerada de los hechos o que promueva la violencia, la crueldad, los delitos y los crímenes. La renuncia a utilizar su influencia profesional con fines distintos a la información y a la formación de la opinión pública. El respeto a la ley de derechos de autor. Derechos del periodista luxemburgués que comprenden: el acceso a todas las fuentes de información requeridas en el desempeño de su deber. El rechazo de toda subordinación contraria a su convicción personal. El rechazo a toda presión e influencia que emane de los anunciantes. Este es un buen código pues respeta las normas lógicas y solo repite los conceptos de la libertad de expresión y que el periodista luxemburgués debe acertar la responsabilidad de sus escritos.

Malta. El Código de Ética Periodística de Malta es uno de los más recientes, al ser aprobado por la Comisión de Ética de la Prensa de Malta y por el Club de Prensa de Malta el año 2002. Este organismo es el que recoge las quejas de los ciudadanos. Algo parecido a la Comisión de Quejas del Reino Unido, o de la Comisión Deontológica de la FAPE en España. Consta de 12 artículos recogidos bajo los siguientes titulares de capítulos: autorregulación y complacencia, conductas antiéticas, reportajes sobre crímenes, suicidios y procesos penales, 
sobre como se debe informar acerca de estos temas, objeción de conciencia, protección de la juventud y de la infancia y las sanciones a quienes no cumplan con este Código Ético. No resulta ser un buen código al repetir algunos conceptos varias veces.

Países Bajos. Este código fue originalmente adoptado por el II Congreso Mundial de la Federación Internacional de Periodistas, el 28 de abril de 1954 y corregido en el XVIII Congreso, el 6 de junio de 1986. Resumimos los nueve artículos que lo componen: el primer deber de los periodistas es el respeto a la verdad y al derecho del público a la verdad. Los periodistas defenderán en todo momento los principios de libertad informativa, así como el derecho a expresar comentarios razonables y críticos. Los periodistas deberán informar solo de los hechos sobre los cuales conozcan su origen. Los periodistas no deberán suprimir información esencial o falsificar documentos. Los periodistas usarán solamente métodos justos para obtener información noticiosa, fotografías y documentos. Los periodistas deberán corregir cualquier información publicada que pueda ser dañina e inexacta. Deberán acatar el secreto profesional respetando la identidad de la fuente de información. Los periodistas no deberán hacer discriminación de personas por ningún motivo basado en: la raza, el sexo, las preferencias sexuales, el idioma, la religión, la política, y los orígenes nacionales o sociales. Los periodistas deberán considerar como una grave ofensa profesional lo siguiente: El plagio, la tergiversación maliciosa, la calumnia, la injuria, el libelo y las acusaciones infundadas, la aceptación del cohecho en cualquier forma, ya sea por publicar o suprimir información. Los periodistas dignos de ese nombre deberán considerar como un deber la observancia fiel de los principios establecidos. Este es un excelente código de ética profesional de periodista, pues solo es reiterativo en un principio que merece la pena repetirlo: el servicio a la verdad, objetividad, exactitud, precisión en la medida de las posibilidades. Constituye éste el primer principio deontológico de todo periodista, por eso, creo que bien merece la pena que se le mencione hasta tres veces.

Polonia. El Código de Ética, polaco fue adoptado por primera vez por el III Congreso de la Asociación de Periodistas de la República de Polonia (AJRP) en septiembre de 1991. Este Código es el cuerpo básico de las normas que han de cumplir los periodistas polacos pertenecientes a la AJRP en sus actividades profesionales. Posteriormente fue adoptado el 29 de marzo de 1995, en Warsovia, 
por las asociaciones y sindicatos polacos editores y medios audiovisuales de radio y televisión, tanto públicos como privados. Este cuerpo básico de normas éticas consta de 15 principios que sumariamos a continuación: La obligación de un periodista es ir tras la verdad y publicarla. La manipulación de los hechos es ilícita. Cualquier comentario personal o hipótesis debe ser claramente separada de la información. Especial exactitud debe darse a la información. Un autor está obligado a rectificar voluntariamente la información que, después de ser publicada, se revele falsa o inadecuada. El periodista está obligado a guardar y preservar el secreto profesional. No debe ser violada la protección de la vida privada de personas. Es inadmisible: usar palabras injuriosas que lesionen la dignidad humana; interponer críticas con las cuales se degrade a una persona ante la opinión pública; es inadmisible suponer la culpabilidad de un acusado antes de ser sentenciado por la corte; se prohíbe absolutamente cualquier publicación que propague la guerra, la violencia, y que ultraje o injurie los sentimientos de las personas religiosas y de los no creyentes; así como los sentimientos nacionales, los derechos humanos, la ascendencia étnica y cultural, y que aliente la difusión de la pornografía. En aras de proteger al periodista contra la pérdida de independencia profesional, no le está permitido aceptar cualquier beneficio para él o para su familia por publicar u ocultar materiales periodísticos. La protección de los derechos de autor es una norma ética esencial. El plagio abierto o encubierto, interno o externo, no es aceptable la violación de esa norma. La actividad que daña la dignidad de otros periodistas o genera deslealtad profesional está prohibida. Es censurable cumplir el orden jurídico violando las normas éticas de la profesión periodística. La inobservancia del Código da lugar a que el ofensor rinda cuentas. Por la inobservancia de principios y normas del Código, la Corte Periodística competente establece sanciones de acuerdo con el grado de la falta cometida. Este es uno de los mejores códigos de toda la Unión Europea. No se repiten los principios éticos y además nos ha sorprendido sobre manera este párrafo, por ser el único código que lo lleva dentro de su texto. Y que quiere indicar que la ética profesional, debe de estar por encima incluso de las normas jurídicas. Al menos eso es lo que yo interpreto en las siguientes palabras con las que termino: Es censurable cumplir el orden jurídico violando las normas éticas de la profesión periodística.. 
Portugal. Código aprobado por el Sindicato de Periodistas de Portugal, el 4 de mayo de 1993. Resumimos el decálogo de los principios deontológicos de que consta este Código, que son, entre otros: El periodista debe revelar los hechos con rigor y exactitud e interpretarlos con honestidad. La distinción entre noticia y opinión debe quedar clara a los ojos del público. Debe combatir la censura y el sensacionalismo, y considerar la acusación sin pruebas y el plagio como graves faltas profesionales. El periodista debe luchar contra las restricciones en el acceso a las fuentes de información y las tentativas de limitar la libertad de expresión y al derecho de informar. Además, debe utilizar medios legales para obtener información, imágenes y documentos, evitando abusar de la buena fe de las personas. La identificación como periodista es una regla. Otros procedimientos para conseguir información solo se pueden utilizar por razones de incuestionable interés público. El periodista debe asumir las responsabilidades por todos sus trabajos y actos profesionales, así como proponer la inmediata rectificación de las informaciones que se revelen inexactas o falsas. El periodista debe también rechazar actos que violenten su conciencia. Como criterio fundamental, debe identificar a sus fuentes. Pero no debe revelar, incluso en un juicio, sus fuentes confidenciales ni incumplir los compromisos asumidos. El periodista debe salvaguardar la presunción de inocencia de los inculpados hasta que haya una sentencia firme. El periodista no debe identificar, directa ni indirectamente a las víctimas de crímenes sexuales o a los delincuentes menores de edad. El periodista debe rechazar el trato discriminatorio de las personas basado en su color, raza, credo, nacionalidad o sexo. El periodista debe respetar la vida privada de los ciudadanos, excepto cuando fuere causa de interés público o la conducta del individuo contradiga valores y principios que públicamente defiende. El periodista debe rechazar funciones, tareas y beneficios susceptibles de comprometer su independencia e integridad profesionales. Buen código que solo es reiterativo en defensa al bien público o común, como primacía a los bienes particulares y a los intereses personales. Lo que es una buena norma de comportamiento ético.

Reindo Unido. Código elaborado por las empresas periodísticas de Gran Bretaña y ratificado por la Comisión de Reclamaciones a la Prensa en abril de 1994. Última revisión del Código de Prácticas de la Comisión de Quejas de la prensa fue el 28 de abril de 2004. Siendo éste prácticamente el último revisado 
dentro de los países de la Unión Europea. Otro código diferente fue aprobado por la Unión Nacional de Periodistas Británicos, el 29 de junio de 1994. Analizamos, presentamos y estudiamos la última versión de 2004 y resumimos en titulares. Los principios más importantes son éstos: verdad, objetividad, exactitud, oportunidad de réplica, intimidad y vida privada, acoso y hostigamiento, intrusión e intromisión en el dolor y tristeza, dos capítulos dedicados a los niños. Uno simplemente titulado niños y un segundo capítulo bajo el título de: niños en casos de sexo. Otro capítulo con el solo título de "hospitales". Reportajes sobre crímenes. Clandestinidad y subterfugio. Victimas de asaltos sexuales. Discriminación. Periodismo financiero. Fuentes confidenciales. Pagos a testigos en los juicios criminales. Pago a los criminales y el interés público. Nos parece un buen código al ser el último revisado, pero no es bueno en cuanto que repite mucho los temas fundamentales y los principios de ética periodística más sobresalientes.

República Checa. El Código de Prácticas de la Prensa de la República Checa fue aprobado por la asamblea general de la Unión de Editores el 5 de septiembre de 2000. Este código es la base de la autorregulación de la industria de los editores de prensa periódica en la República Checa, y sus principios deontológicos sirven para salvaguardar la ética profesional de los periodistas en esta República. En ningún momento se trata de leyes positivas que obliguen como derecho. Tanto los editores como los periodistas deben asegurar que estos principios deontológicos deben ser considerados como un material valioso que les ha se servir de guía práctica en el ejercicio profesional de este país. El no cumplimiento de estos principios, su interpretación, o cualquier desajuste con el código, serán resueltos y sancionados por el Consejo de Prensa de la República Checa, que es un organismo individual de la Unión de Editores. Sus decisiones deben ser respetadas y publicadas sus decisiones. En cuanto a los contenidos de este Código por capítulos son estos: la libertad de prensa, su papel y su interés público. Veracidad, verdad, exactitud y precisión en la información. Protección de la personalidad. Protección de la intimidad y vida privada de las personas y de los datos de carácter personal o íntimo. Conservar la presunción de inocencia. Servicio al interés del público en general y no a los intereses privados de los periodistas. Por último, la protección de niños y jóvenes y de sus intereses, de tal manera que ni los nombres ni las fotografías de ellos deben aparecer en 
la prensa, con el fin de que al alcanzar la adultez puedan volver a la sociedad. Cada uno de estos capítulos los hemos explicitado en el cuadro general de los códigos éticos de los 27 países de la Unión Europea. A pesar de ser uno de los códigos más recientes, no se lo considera bueno, pues conceptos como la verdad, los repite hasta seis veces. También reitera en varias ocasiones otros conceptos importantes, cosa que no se debe hacer en un buen modelo de código.

Rumanía. El Código de Ética de Prensa de Rumanía fue establecido por las organizaciones miembros de la Media Organizations Convention. Reunidas en la Sinaia, desde el 9 al 11 de julio de 2004. Consta de varios capítulos cuyos títulos principales son los siguientes: Después de un Preámbulo, continúan los temas siguientes: el papel del periodista. La conducta profesional que a su vez se subdivide en otros subtítulos como: el respeto a los derechos humanos. Reglas de edición. La protección de las fuentes. Cómo se debe conseguir la información. Abusos que se pueden cometer a través del abuso del status del periodista. Independencia o clausula de conciencia. Corrección de errores y derecho de réplica. Finalmente se mencionan algunos de los derechos del periodista. Resulta un código bastante reiterativo pues conceptos como la libertad de expresión, la libertad de prensa y el servicio al buen público o bien común son repetidos hasta en cinco artículos del Código diferentes. La verdad, objetividad y la exactitud en la información se repiten por lo menos en cuatro ocasiones. La obligación del periodista de respetar las instituciones sociales se encuentra al menos en tres artículos diferentes del Código. Concluimos que a pesar de ser uno de los códigos más recientes en cuanto a su formulación, sin embargo, deja muchas deficiencias lógicas y estructurales por lo cual no nos parece un buen código, al menos en su parte como continente. Otra diferencia es en cuanto a su contenido semántico que es actual, moderno y recoge los más importantes principios de la deontología periodística.

Suecia. El Código de Conduzca para la Prensa, la Radio y la Televisión fue adoptado originalmente con la cooperación del Consejo de la Prensa de Suecia en 1978. Posteriormente se hizo una nueva revisión en agosto de 1994. La última, que es la que está en vigor, y la que hemos analizado y estudiado data de septiembre de 1995. En esta versión intervinieron en su redacción, la cooperación del Consejo de Prensa que a su vez está compuesto por el Club de Editores de prensa, la Asociación de Periodistas Suecos, el Sindicato de 
Editores de Periódicos Suecos, la Radio Pública Sueca, la Televisión Pública de Suecia y el Sindicato de radio y televisión educacional. En su contenido encontramos los siguientes capítulos: I Reglas sobre publicidad, que comprende a su vez los siguientes subtítulos: difusión de noticias exactas. Ceda espacio a la réplica. Respete la intimidad y la vida privada de los individuos. Respete la integridad personal. Sea cuidadoso en el uso de fotografías. Escuche a todas las partes. Tenga cuidado con la publicación de nombres. II. Reglas profesionales. Entre las que se encuentran: Cómo obtener material. Tiempo de emisión de la prensa. III. Reglas contra la publicidad en espacios periodísticos Consta de una Regla principal y varias generales. Lo específico de cada uno de estos tratados lo hemos recogido en el cuadro general donde hacemos el estudio analítico de todos y cada uno de los párrafos, señalando su análisis de contenido semántico. Por lo que se refiere a su presentación o estructura al principio deontológico que más importancia da es el hecho de que el periodista debe ser íntegro en su ejercicio profesional y no se debe dejar sobornar de ninguna forma, bien sea para no publicar información o bien para publicarla. Este concepto está presente en una media docena de artículos de este Código, lo que nos parece demasiado, aunque comprendemos la importancia que se da en Suecia a este concepto. Le siguen en importancia cuantitativa los principios éticos de servir en primer lugar al bien público o bien común antes que a los conflictos de intereses o a los intereses personales o individuales de los periodistas suecos. También se ocupa en muchos artículos de la ética de la fotografía de prensa y el no a la pornografía. Estos conceptos son reiterativos en al menos en cinco artículos diferentes de este Código. Mucha importancia cuantitativa se da al tema de la verdad, la objetividad, la exactitud y la precisión en la información. No es que tengamos nada en contra de este principios, pues para nosotros es el primero que debe aparecer cuantitativa y cualitativamente en un elenco de principios de ética periodística, al menos en el nuestro es así, este deber u obligación de periodista dimana del derecho natural que el público o el lector, tiene al derecho a recibir información veraz. Al menos se menciona en cuatro artículos diferentes, lo que nos parece demasiado. Se mencionan en al menos tres ocasiones los conceptos de: corrección de errores y derecho de réplica, la obligación de respetar la intimidad y vida privada de las personas y de los datos de carácter personal o íntimo, el hecho de que el periodista sueco no deba hacer ni publicidad ni pro- 
paganda mientras ejerza su profesión en un medio informativo de titularidad pública o estatal. En general los países nórdicos, y Suecia lo es, se detienen mucho en sus respectivos códigos en lo que podríamos denominar como la deontología de los crímenes y de los suicidios, así como de la protección de la juventud y la infancia y de que ni sus nombres, ni sus fotografías deben aparecer en la prensa. Todos estos conceptos son reiterados al menos tres veces. Bien en cuanto a sus contenidos semánticos, pero no tan bien en cuanto a su formulación o articulación

España. Dejamos a nuestro país para este último lugar de los países de la Unión Europea, pues así se nos indicó, al hacernos el encargo de este trabajo. Hagamos un poco de historia de la Ética Periodística en España. El decreto oficial 900/2972, dictado por el entonces Ministerio de Información, el 16 de marzo de 1972, en tiempos de la dictadura, del General Franco, disponía la constitución de un Jurado de Ética Periodística, al cual se encomienda el tratamiento de las infracciones a los principios generales de la profesión periodística. Estos principios están contenidos en seis artículos que figuran en un anexo del decreto. De conformidad con el artículo primero, en el desempeño de sus funciones el periodista debe ajustarse a la moralidad cristiana, a los principios del Movimiento Nacional y a las leyes fundamentales del Estado. La base para la actividad profesional del periodista debe ser el servicio a la verdad y el respeto a la justicia y a la rectitud de propósito. La meta del periodista debe ser informar, educar y servir a la opinión nacional. El artículo segundo recuerda al periodista los requisitos de seguridad nacional y le advierte que debe evitar cualquier noticia, que sea contraria a la moralidad y a las buenas costumbres. Se lo impone, además, la obligación de evitar toda deformación y rechazar cualquier presión que tienda a alterar la exactitud de las noticias y la imparcialidad de su opinión o juicio crítico, cuando éstos sean honradamente expresados. Otros artículos estipulan el respeto a la intimidad y vida privada y al secreto profesional (exceptuando el caso de la cooperación necesaria con la ley). Una disposición bastante inusual establece que el periodista debe lealtad a la empresa para la cual trabaja (...) en la medida en que sea compatible con su conciencia profesional, con la moral pública, con la ley y con los principios fundamentales del Estado. 
Como fruto de la investigación llevada a cabo con motivo de nuestra tesis doctoral que llevaba por título: Códigos éticos de la profesión periodística: análisis comparativo (1979). A través de un resumen de las conclusiones de la misma, la entonces Secretaria de Estado de Información, del Palacio de la Moncloa, bajo la dirección del Sr. Secretario de Estado para la Información, Joseph Meliá, el Gobierno de la UCD, publicó un Proyecto de código de ética profesional del periodista, con el fin de que sirviera de normativa para todos los periodistas nacionales. Del contenido semántico de todos los códigos de deontología que estudiamos para nuestra tesis, presentamos un elenco de 37 principios por orden decreciente cuantitativo según las frecuencias de aparición como muestra de los resultados de nuestra investigación. Pero antes de pasar a los artículos del proyecto de código que hicimos en su día, la autoridad competente del Presidente Adolfo Suárez, promulgó este código con estas palabras: Conscientes de que la libertad de expresión y el derecho de la información son derechos fundamentales que todo ser humano tiene en nuestra sociedad. Conscientes, así mismo, de que el poder de influencia de la prensa en la actualidad y su función en una sociedad democrática y pluralista exige una alta responsabilidad en el cumplimiento de la profesión periodística; promulgamos este Código que explicita los derechos y deberes éticos de la profesión, y a los que, en conciencia, es preciso subordinar toda actividad periodística.

Hasta aquí la nota oficial de la autoridad competente. Mi comentario es que si nos atenemos a la definición clásica de ley sus tres condiciones fundamentales que son:

1. Ordenación de la razón,

2. Que sea para el servicio al bien común o bien público y

3. Que esté promulgada por la autoridad competente, en ese caso este código, sería el único código aprobado oficialmente por el gobierno de la Nación. Los contenidos semánticos de las conclusiones de nuestra tesis doctoral fueron estos:

1. La primera obligación de todo periodista es el servicio a la verdad, de la forma más objetiva, precisa y exacta posible en virtud del derecho natural que el público en general tiene a conocer la verdad.

2. Todo periodista tiene el deber de guardar el secreto profesional respetando las fuentes de información y las confidencias y no revelando los nombres de los informantes, ni nada que ellos prohíban comunicar. 
3. Todo periodista, con el fin de salvaguardar su libertad y su independencia, debe mantener su dignidad e integridad profesional no admitiendo ninguna forma de soborno.

4. La calumnia, la acusación sin fundamento, la difamación, la injuria y el plagio deben ser considerados por todo periodista como las faltas más graves que puede cometer en el ejercicio honesto de su profesión.

5. El periodista considera como una de sus principales obligaciones el deber de rectificar prontamente y de forma libre y espontánea, cualquier información errónea o inexacta; así como el conceder el derecho de réplica, rectificación o respuesta a toda persona que lo solicite.

6. El periodista tiene la obligación de salvaguardar el derecho natural que tiene toda persona a su intimidad y vida privada, privacidad, tanto propia como familiar.

7. El derecho a la libertad de información y de expresión, que comprende también el derecho al comentario y a la crítica, es un derecho inalienable del periodista.

8. La primacía del servicio al bien común, bien social, interés del público o de los demás, debe ser tenido como un objetivo primordial a conseguir por todo periodista. 9. El periodista jamás deberá mostrar en sus publicaciones discriminación alguna entre personas, sea ésta por razones de raza, color de la piel, sexo, religión, opinión política, origen nacional o social, etc.

10. En la obtención de noticias, fotografías o documentos de cualquier índole, el periodista solamente podrá usar los medios que sean justos, dignos, honestos y razonables. Hasta aquí los diez contenidos con más frecuencias que aparecieron en las conclusiones de los códigos de ética periodística estudiados para llevar a cabo nuestra tesis doctoral y que fue publicada en el año 1980.

Posteriormente vendrían, el Código aprobado por la Federación de Asociaciones de Periodistas de España (FAPE), que es actualmente, la entidad más representativa del periodismo español. Agrupa a 45 Asociaciones de la Prensa con 12.500 miembros y tres Asociaciones sectoriales de periodistas, que suman otros 3.000 asociados. Las Asociaciones federadas en la actualidad son: Albacete, Alicante, Almería, Aragón, Ávila, Badajoz, Burgos, Cáceres, Cádiz, Cam- 
po de Gibraltar, Cantabria, Castellón, Ceuta, Ciudad Real, Córdoba, Cuenca, Granada, Guadalajara, Huelva, Jaén, Jerez de la Frontera, La Coruña, La Rioja, Lanzarote-Fuerteventura, Las Palmas, León, Lugo, Madrid, Málaga, Melilla, Mérida, Murcia, Oviedo, País Vasco, Pamplona, Santa Cruz de Tenerife, Santiago de Compostela, Segovia, Sevilla, Soria, Talavera de la Reina, Toledo, Valladolid, Zamora y Unió de Periodistes Valencians.

La FAPE es una Organización profesional sindical acogida a la Ley 91/1977, Ley de Asociaciones Profesionales, y legalizada con el número 896. Se rige por unos Estatutos aprobados en la Asamblea General de Burgos en 2006 y tiene su sede en Madrid, Juan Bravo 6, 28006. En este sentido, los periodistas, integrados en la Federación de Asociaciones de Periodistas de España, se comprometen con la sociedad a mantener en el ejercicio de su profesión los principios éticos y deontológicos que le son propios. En su virtud, la Asamblea General de la Federación de Asociaciones de Periodistas de España promulgó los principios y normas deontológicas de la profesión periodística o mejor conocido como el Código de la FAPE, reunida en Granada, el 28 de noviembre de 1993. Además la FAPE cuenta con la Comisión de Quejas y Deontología como la Press Complaints Commission (Comisión de Quejas a la Prensa) del Reino Unido con su propio Código de Ética Periodística, aprobado en abril de 1994 y que hemos analizado en este estudio ya.

Por otro lado está Código Europeo de Deontología del Periodismo, (Estrasburgo, 1 de julio de 1993), aprobado por el Parlamento Europeo de Estrasburgo, cuyo ponente fue el Catedrático de la Universidad Complutense, Manuel Núñez Encabo, quien a la sazón es, Vicepresidente de la mencionada Comisión de Quejas y Deontología de la FAPE. Estos serían los tres únicos códigos aprobados en España, a nivel nacional.

Pues a nivel regional contamos con la presencia de la Declaración de Principios de la Profesión Periodística, que es como el Código de los Periodistas Catalanes, aprobada el 1 de noviembre de 1992, por el Collegi de Periodistes de Catalunya y el Consejo Consultivo de la entidad, en el que están representados los diferentes medios de comunicación de Cataluña, que coincidieron en la necesidad de promover una iniciativa colectiva de la profesión periodística, encaminada a reafirmar los derechos de la libertad de expresión y de información y a defender la existencia de una prensa libre y responsable en el marco de 
una sociedad plural y democrática. Esta iniciativa se inscribe en la reconocida tradición democrática e independiente del colectivo profesional de la prensa de Cataluña y se inspira en actuaciones parecidas recientes, adoptadas en países de gran trayectoria democrática y con una sólida institución periodística. La propuesta se enmarca en el seno del debate social permanente sobre la función y las atribuciones de los medios de comunicación, y pretende estimular la reflexión y la crítica colectivas para una mejor relación entre la prensa y la sociedad a la que se dirige y sirve. Con esa finalidad, invita y anima a las entidades y a los profesionales del ámbito de la información y la comunicación en general a reafirmar los principios deontológicos que sustentan la actividad periodística, suscribiendo y asumiendo voluntariamente los criterios recogidos en la Declaración de Principios de la Profesión Periodística, que es como el Código de los Periodistas Catalanes,

\section{Principios éticos de los Códigos deontológicos españoles}

La Declaración de Principios de Conducta de los Periodistas considera como grave ofensa profesional varios comportamientos ilícitos como son el plagio, la distorsión maliciosa, la calumnia, injuria, libelo, acusaciones infundadas y la aceptación de sobornos en cualquier forma por publicar o suprimir determinada información. Otro de los ejemplos alude a la ética de la práctica del robo de informaciones por parte del periodista. En general, los documentos españoles que hacen referencia a la ética periodística reiteran la necesidad de conseguir la información por métodos lícitos. Algunos se refieren además a que esos métodos deben ser honestos o dignos. Están de esta forma intentando cubrir por la vía de lo moral lo que pueden ser lagunas importantes en las diferentes legislaciones. Se plantea otro problema cuando la información difundida se basa en datos que han sido ofrecidos por la fuente con la condición de que no se hagan públicos. Es decir, cuando se viola lo que se conoce como un off the record. O lo que es lo mismo, la violación del secreto profesional del periodista. Los códigos deontológicos suelen referirse expresamente a estas informaciones y piden siempre que se respete la confidencialidad, aunque algunos matizan que el off the record queda sin validez si otra fuente da la misma información sin imponer restricción alguna. Lo que la fuente no puede hacer nunca es secues- 
trar la información por la vía de darla off the record a los periodistas. De ahí que algunas veces, cuando los periodistas sospechan que puede haber alguna intención de este tipo tras una confidencia, se lancen a intentar confirmarla por otras vías, para poder difundirla sin romper norma deontológica alguna. En este aspecto es de relevante importancia mantener el secreto profesional del periodista que tiene una garantía reconocida en España a nivel constitucional en el artículo 20 de nuestra Carta Magna de 1978, que da a la fuente el derecho a no ser revelada su identidad ante nadie, ni siquiera ante el juez en los tribunales de justicia. Sin embargo, hay que considerar que según el Código Deontológico de la FAPE, si la información, que ha revelado dicha fuente pone en peligro la vida de las personas o se demuestra que esta ha falseado su contenido de forma consciente, el periodista está en la obligación de no reservar la confidencialidad de la fuente. La inmediatez informativa, la exclusividad y la exigencia de la difusión lo más pronto posible de las noticias, motiva buena parte de los comportamientos que se sitúan al margen de la legalidad y de la licitud.

Casi todas las regulaciones existentes en España recogen las normas que se aprenden en las facultades de Ciencias de la Información y de la Comunicación y Periodismo: el respeto a la verdad, la objetividad, la exactitud, en la precisión en la información en la no manipulación, en virtud del derecho que el público tiene a conocer la verdad. Para ello, se debe perseguir la objetividad y la verdad aunque se sepan inaccesibles, contrastar los datos con todas las fuentes necesarias, diferenciar entre información y opinión, y enfrentar, cuando existan, las versiones diferentes sobre un hecho. En la búsqueda de la objetividad, los periodistas se suelen enfrentar a todo tipo de presiones. Los profesionales españoles consideran que la mayor parte de estas presiones, en nuestro país, provienen de los poderes económicos, seguidas de las de las propias empresas y en menor medida del Gobierno de turno y de los anunciantes. En España existen alrededor de una docena de medios o colectivos profesionales que se han dotado de una regulación ética, articulada en forma más o menos concreta y plasmada en códigos entendidos como tales, en estatutos de redacción, convenios colectivos e incluso libros de estilo. La mayoría han surgido en la década de los noventa y en todos los casos, se trata de consideraciones éticas y deontológicas que afectan a grupos profesionales como: la Asociación de Periodistas de Información Económica (APIE), el Colegio de Periodistas de Cataluña, la Federación 
de Asociaciones de la Prensa de España (FAPE)-, o medios de gran difusión: El País, El Mundo, ABC, El Periódico de Catalunya, el grupo Correo, Europa Press, la COPE, RTVE, y la revista Actualidad Económica.

Todas las profesiones requieren para su ejercicio de una ética, es por esto que los profesionales están sometidos a ciertos controles, en cuanto al cumplimiento de los códigos éticos propios de su actividad por parte de los colegios profesionales. En España, por ejemplo, tenemos, el del Colegio profesional de periodistas de Galicia, el del Colegio de periodistas de Cataluña, o el Colegio de periodistas de Valencia y otros colegios profesionales que desconozcamos por el momento en el territorio nacional.

La búsqueda de objetividad del periodista y el reconocimiento de la fuente de comunicación son realidades relacionadas en la comunicación periodística. Uno de los factores a la hora de interpretar la situación periodística es la confianza y profesionalidad de la fuente periodística. Dicha credibilidad por parte del periodista, marcará su profesionalidad para con los medios de comunicación. Esta característica en la fuente, viene determinada por dos factores fundamentales: la confianza y la experiencia, los cuales incrementan la eficacia del mensaje en aquellas áreas en las que la fuente se considera experta. Por esta razón no es extraño que muchas comunicaciones en la vida social y política aparezcan avaladas por expertos. Un factor a destacar es la concentración, de los medios de comunicación a nivel global y del periodista en el desarrollo de su actividad, en determinadas fuentes informativas. Dichas fuentes se acercarían a los puntos de vista más próximos al profesional periodista, en lugar de garantizar una diversidad informativa. Una de las consecuencias más claras de la concentración de un medio en pocas manos, es la asimilación por parte del potencial lector de este hecho, estableciendo los temas que se deben tratar y debatir. Esta concentración puede ocasionar de igual modo que los propios periodistas asuman el papel de expertos. Uno de los autores que mejor ha resumido los principios éticos generales de los Códigos deontológicos españoles, ha sido, a mi entender, César Coca, profesor de la Universidad del País Vasco, en su artículo: códigos éticos y deontológicos en el periodismo español, que resumimos en titulares: Después de una pertinente introducción, Cesar, desarrolla los siguientes apartados: principios éticos en general, después, desciende al terreno de lo específico y concreto: la intimidad y el honor, los menores y la protección 
de la juventud y la infancia, los discriminados en el periodismo español, el periodista sospechoso, actividades incompatibles con el ejercicio profesional del periodista español, las obligaciones que tienen las empresas informativas en España, del robo al plagio, lo que falta en los códigos españoles, el vigilante de la ética del periodismo español y termina con unas conclusiones acertadas sobre cuál es la situación de la ética de los periodistas españoles.

En opinión de Cesar Coca los códigos españoles adolecen de lo siguiente. Les falta, en primer lugar, la credibilidad de algo tan importante en una sociedad democrática como es la información. Hay dudas que quedan después de la lectura de los códigos: En cuanto a la aceptación de regalos, los códigos españoles no se refieren a la obtención de prebendas personales difícilmente cuantificables. Desde un crédito a un tipo de interés inferior al de el mercado, o al reservado a los mejores clientes sin que el periodista lo sea, hasta la posibilidad de poner junto al nombre, a la hora de identificarse ante determinadas instancias. ¿Es ético pagar por adquirir información? En algunos tipos de publicaciones es práctica habitual, pero ¿debe hacerse? ¿Hay que pagar a un famoso por poder conseguir algunos datos acerca de la boda de sus hijos, o por poder tomar fotos de su boda, o es mejor no hacerlo y no dar esa información? ¿Es legítimo, programar las exclusivas para que tengan un mayor impacto en la opinión pública? Todos estos son parte de los interrogantes que se hace Cesar Coca. ¿Basta sólo con la existencia de códigos o es preciso algún tipo de organismo que obligue al cumplimiento de sus normas? Los códigos existentes en España no incluyen en general la previsión de un órgano que vigile su cumplimiento. Algunos se remiten a un reglamento futuro. Otros, simplemente, no contemplan ni vigilantes ni sanciones. Pero la simple existencia de códigos es ya un avance sustancial en la profesión periodística. No hay que olvidar, por último, que hay especialistas, como el profesor de Valencia, Hugo Aznar, que sostienen que los códigos éticos no son ni útiles ni siquiera convenientes. No son útiles porque de nada sirve pedir unos comportamientos concretos si no se hace nada contra quienes los vulneran. No son ni siquiera convenientes porque, como dice uno de los autores que más ha criticado su existencia, John C. Merrill, "la única ética válida es la que cada persona tiene dentro de sí". Precisamente, de este autor un tanto crítico y contestatario a pesar de su edad de unos noventa años, y no muy creyente en los códigos éticos, acabamos de traducir uno de sus últimos 
libros: LA ÉTICA DEL PERIODISMO. Fundamentos filosóficos de los Nuevos Medios de Información... Editorial de la Universidad Técnica Particular de Loja. UTPL. Ecuador. Septiembre.2007.

Hay tantas dudas sobre la materia que todo parece indicar que los códigos éticos son en realidad un pacto de caballeros. Un compromiso de comportamiento de unos profesionales que responden sólo ante sí mismos y ante su conciencia, porque nada más fácil que burlar muchos de los preceptos que en ellos figuran sin que puedan descubrirlo terceras personas. De ahí que incluso los periodistas más corruptos se conviertan en público, en algunas ocasiones, en adalides de los comportamientos más rigurosamente éticos, para sorpresa de quienes les conocen bien

Sobre algún tipo de organismo que obligue al cumplimiento de sus normas establecidas en los códigos deontologicos, tenemos buenos ejemplos. Uno en el Reino Unido, con la Press Complaints Commission, o Comisión de Quejas a la Prensa. En España la FAPE y su Comisión de Quejas y Deontología, que es un órgano de autocontrol relativo a la deontología periodística que pretende favorecer el entendimiento y el arbitraje entre profesionales del periodismo. Actúa como autoridad moral garantizando así el cumplimiento del Código Deontológico de las asociaciones de la prensa española y sus afiliados, que voluntariamente la aceptan. También en Cataluña, Andalucía y otras regiones españolas donde existen los Colegios Oficiales de Periodistas, como en Galicia y en Valencia, y en otras regiones españolas que nosotros desconozcamos en este momento. Todas ellas velan por el control en la realidad práctica de lo que se dice en la teoría de los textos teóricos de los códigos deontológicos en España.

Sobre todo esto es muy laudable el documento que tenemos en nuestras manos. Se trata de la Memoria de la Comisión de Quejas y Deontología de la Federación de Asociaciones de Periodistas de España (FAPE) 2004-2007. Como muestra del buen funcionamiento de la FAPE en esta materia, y como para muestra vale un botón y a título de ejemplo, nos quedamos con el caso del informe y Resolución del 18 de octubre de 2007 páginas de la 85 a la 94, sobre la protección de la imagen de los menores en la prensa. Aquí se ve la progresiva protección jurídica de los menores a lo largo de la historia, desde el Código de Hammurabi (2.250 a.C.), hasta la protección jurídica de la juventud y la infancia en el artículo 20 de nuestra Constitución de 1978. También se trata en esas 
páginas de la protección de los menores desde el punto de vista deontológico en el periodismo. Se mencionan los lugares que en el Código de la FAPE se hace referencia a la doctrina de este caso concreto y que fueron aplicables en esta situación y por último la aplicación práctica de los principios citados en el apartado anterior al supuesto examinado.

\section{Referencias bibliográficas}

Fairchild, H.P. Diccionario de Sociología. México: Fondo de Cultura Económica. 1963. Citado por: Grazziosi, L. Códigos de ética del Servicio Social. Buenos Aires: Humanitas. 1978.

Laitila, Tiina. Codes of Ethics in Europe en: Karle Nordenstreg (Ed), Report on Media Ethics in Europe. Tampereen yliopisto Tiedotusopin Laitos. University of Tampere. Department of Journalism and Mass Communication. Series B 41/ 1995. 